IJßER

ISSN: 2149-5939
International Journal of Social Sciences and Education Research

Online, https://dergipark.org.tr/tr/pub/ijsser

Volume: 6(3), 2020

Research Article

\title{
The effect of first and second language on the third language: An observa- tional study
}

\author{
Fatma Demiray Akbulut
}

Received date: $16 / 05 / 2020 \quad$ Accepted date: $27 / 06 / 2020$

\begin{abstract}
In recent years, some studies have been conducted on the transfer of the first and second language to the third language in order to investigate cross-linguistic influence. This study aims to analyse the causes of cross-linguistic effects by examining the transfer of L1 and L2 during the L3 acquisition. A total of 7 individuals who learn Italian as L3 participated in the study. Individuals' attitudes in the classroom, writing examples and classroom conversations were examined, their opinions were taken and the effects of L1 and L2 on L3 were examined. The study results show that the more learned languages are typologically close, the easier it is to learn. It also demonstrates that there is no exact evidence in transfer between languages.
\end{abstract}

Keywords: Language transfer; L2 acquisition; L3 acquisition; Language teaching

\section{Introduction}

In addition to the second language acquisition, the linguistic influence that occurred during the third language acquisition has been an important issue in recent years. In the context of linguistic influence and the interaction of the three languages with each other, it is a curious area whether individuals who acquire a third language transfer from their first or second language. It is thought that the role of a previously acquired language during the acquisition of a second language may contribute to understanding how languages are classified in the human mind. Studies in the field of third language acquisition examine the possible interactions of first and second languages in this process during the acquisition of the target language in multilingual individuals. In this context, one of the most important research questions is how L1 and L2 affect L3 acquisition.

L1 or L2 transfer samples seen in multilingual individuals have been studied for years by researchers for cross-linguistic effects. It is possible to answer to the question of why second language learners include L1 features in L2 production. Anderson (1983) emphasizes that in the sense of Transfer Principle, a grammatical form or structure will only be inevitable if there is an already L2 input. In short, L1 structure ought to be steady with normal procurement standards, and favored structures ought to be free, invariant, practically basic and habitually happening morphemes. Kellerman (1983), by examining the transfer perspective in a similar way, states that the student's acknowledgment of consistent shapes between local and target languages encourages or anticipates L2 acquisition. In the event that the two languages are similar to one another in a specific structure, the transfer will be more likely, whereas an obvious distinction will lead to avoiding that target structure.

\footnotetext{
${ }^{1}$ Asst.Prof.Dr., Bolu Abant Izzet Baysal University, School of Foreign Languages, Translation and Interpreting Department, Bolu-Turkey, Email:demirayfatma@gmail.com ORCID: https://orcid.org/0000-0003-0689-8483
} 
Demiray Akbulut, F. (2020). The effect of first and second language on the third language: An observational study. International Journal of Social Sciences and Education Research, 6(3), 294-310.

The linguistic effect happens during the acquisition of other languages. The third language and its relationship with language transfer is still in the explanation of characterizing this language's scope, originality and an appropriate strategy (Cenoz, 2001; De Angelis \& Selinker, 2001; Hammarberg, 2001; Murphy, 2003). It is naturally clear that a multilingual student who acquires an extra language will learn it in an unconscious way and it means that cross-linguistic impact will be more complex when more than two or three languages are in contact.

\section{Cross-linguistic influence}

As shown in the literature, there are lots of variables which affect cross-linguistic phenomenon. The reasons for this transfer are different depending on the language acquisition such as the typological similarity between languages (Anderson, 1983; Cenoz, 2001; Kellerman, 1983, 1995), the level of proficiency in the languages the speaker learns (De Angelis \& Selinker, 2001; Kellerman, 1983; Odlin, 1989), the formal limitation of lexical elements degree (Selinker \& Lakshmanan, 1993), last language effect (Shanon, 1991), foreign language effect (Selinker \& Baumgartner-Cohen, 1995), frequency of use (Hammarberg, 2001); and also other factors such as The Cumulative Enhancement Model (Flynn, Foley \& Vinnitskaya, 2004). On this respect, in literature, several approaches such as L2 Status Factor Model (Bardel \&Falk, 2007), Declarative/Procedural (D/P) Model (Ullman, 2005), Typological Primacy Model (TPM) (Rothman, 2015), The Cumulative Enhancement Model (CEM) (Flynn, Foley \& Vinnitskaya, 2004), The Linguistic Proximity Model (Westergaard, Mitrofanova, Mykhaylyk, \& Rodina, 2017) and the Scalpel model (Slabakova, 2017) have been identified to model grammatical transfer in acquisition of L3.

Most of these models center on the beginning state of consecutive L3 acquisition and hypothesize that a duplicate of either the L1 or the L2 language structure is enrolled as the initial linguistic use for developing L3. To begin with, L2 Status Factor Model (Bardel \&Falk, 2007) claims that L2 has an important role in grammatical transfer since it is the last language acquired in a foreign language structure before L3. Thus, the researchers think that L2 is the initial factor in $\mathrm{D} / \mathrm{P}$ Model. In this model, age and critical period have an important effect on L3 acquisition and at this time, procedural and declarative memory play an important role in that learners place L3 in the declarative memory alongside L2 (Bardel \& Falk, 2012). As another model, TPM offers that this grammatical transfer happens when there is a similarity between languages in terms of lexicology, phonology, morphology and syntax. In this model, the most similar language acquired beforehand will be the most transferred language in L3 acquisition. The next model is CEM, which can be identified as the model offering language selective transfer. Thus, the transfer depends on L1 or L2 properties in L3 acquisition. The LPM and Scalpel model, on the other hand, claim that structural similarity between languages is important and or this similarity decides the transferred language which has a closest grammatical structure to L3 (Hopp, 2019).

To sum up, there are lots of indicative models expressing transfer and cross linguistic effects in L3 acquisition and these approaches can be analysed in terms of proficiency, target language exposure, linguistic awareness, age-educational background and language typology. Although this study cannot analyse all these variables in depth, the multilingual perspective will be examined in the light of observations, by providing an overview of cross-linguistic effect and specific variables that affect third language acquisition. 
Demiray Akbulut, F. (2020). The effect of first and second language on the third language: An observational study. International Journal of Social Sciences and Education Research, 6(3), 294-310.

\section{Learner and language-based variables}

\subsection{Proficiency}

Proficiency is one of the foremost critical components that decide the possibility of language transfer. Language transfer among researchers is more likely to happen at lower capability levels (Poulisse \& Bongaerts, 1994). This affirms the transfer point of view as a technique since students use their L1 to fill a lexical or syntactic crevice when they need linguistic expressions in L1 (Fuller, 1999; Ringbom, 1986). However, Odlin (1989) states that the correlation between low L2 competence and transfer applies primarily to negative transfer, while certain types of transfers, such as the use of the same word, appear even at high qualification levels.

Proficiency is obvious within the discourse of L3 acquisition, and the common agreement is the low L3 capability since of the low transfer from L2 to L3 (Dewaele, 2001; Hammarberg, 2001). In any case, given the complex linguistic setup of the multilingual language, the impacts of proficiency must be taken into consideration in all languages the speaker knows. The speaker must have a certain degree of L2 competence to supply material to the language transfer (Hammarberg, 2001). In addition, this demonstrates that L2 transfer is basically a superficial process. On the other hand, when L1 and L3 are typologically distant (De Angelis \& Selinker, 2001; Ringbom, 1986, 2001), the transfer comes from L2, which depends on the individual's competence.

\subsection{Target language exposure}

This variable is in direct interaction with age and competence. The duration of the nature of the target language learned or the amount of exposure to the target language as a foreign language plays an important role in transfer. The amount of exposure has a strong effect on the possibility of both positive and negative language transfer (Odlin, 1989). Jarvis (2000) states that the results of his study on Finnish and Swedish L2 English learners show that the effects of exposure to L2 vary by task. From the point of L3 acquisition, according to Dewaele (2001), increased L3 exposure leads to less language transfer. This is probably due to the fact that multilingual individuals need more cognitive resources. Another interesting point with respect to the multilingual circumstance is that the amount of exposure to L2 contains a coordinate effect on the possibility of being a transfer source to L3 (Murphy, 2003).

\subsection{Linguistic awareness}

The linguistic awareness of the student is a critical variable in language performance and acquisition forms and is generally related to the instructive background. Awareness is not restricted to linguistic structures and semantics, it moreover influences phonological, pragmatic and sociolinguistic information, and cross-linguistic influence happens in any of these ranges. It is also claimed that the linguistic awareness of an L3 student is essentially diverse from the monolingual learning of their first L2 (Cook, 1995; De Angelis \& Selinker, 2001; Grosjean 2001). Cook (1995) defines multi-competency concept implying multilingual linguistic competence, characterized by expanded linguistic awareness, greater imagination and cognitive adaptability and a variety of mental capacities. The researcher states that the features of L3 learners, such as involuntary code modification and lexical access errors, ought not to be seen as failure, but as a proof of the special and adaptable linguistic arrangement of the multilingual language.

Copyright (C) by International Journal of Social Sciences and Education Research ISSN: 2149-5939 
Demiray Akbulut, F. (2020). The effect of first and second language on the third language: An observational study. International Journal of Social Sciences and Education Research, 6(3), 294-310.

\subsection{Age and educational background}

It is argued that second language acquisition by young children is driven by UG and target language input, following a process similar to first language acquisition (Selinker \& Lakshmanan, 1993). However, Odlin (1989) states that although young learners show less L1 effects in phonology, children 4-10 years old tend to adhere to a single syntactic pattern and adults are more flexible. Therefore, although the "young is better" principle is basically true, other possible variables should be taken into consideration. As Hofer and Jesner (2019) stated in their study, early and extensive contact with a second and/or third language can have significant positive effects on young learners' linguistic and cognitive performance. Students who have developed a high level of language abilities in their mother tongue will likely find that these skills also enhance and develop second language acquisition (Odlin, 1989). It should be noted that the students' educational background is less analysed in language transfer studies than other variables such as language typology or language exposure. While it can intuitively assume that less educated students will show less restrictions on language transfer in a natural learning environment, this assumption needs to be clearly demonstrated by empirical evidence.

\subsection{Language typology}

Typological closeness between L2 and L3 facilitates language transfer (De Angelis \& Selinker, 2001; Fuller, 1999; Hammarberg, 2001; Ringbom, 2001; Williams \& Hammarberg, 1998). One of the most important proposed models is Typological Primacy Model (TPM). In this model, transferring the features can be explained with the existing or perceived typological proximity of the languages. In addition, TPM predicts that it can play a decisive role in inter-linguistic interaction regardless of the order of acquisition (Kellerman, 1983) or existing typological proximity. From the perspective of Cumulative Enhancement Model (CEM) Flynn, Foley and Vinnitskaya (2004) predicted that previously acquired languages would have influences on the acquisition of L3 as long as they are similar to the third language. If there is no similarity, there would be no transfer during the interaction between languages. This saying leaves a gap in explaining the effect of the first or second language features that are not similar to each other.

\section{The current study}

The current study shows the description of L3 (Italian) acquisition process with regard to seven participants who have come to Italy to learn Italian with different purposes. The research examines the findings of three-months-observation on the language acquisition among participants with different mother tongues and L2s (see Table 1). This study tries to find out the effects of knowing French or English as a second language on acquisition of Italian as a third language. It also aims to examine whether having a different mother tongue influences third language acquisition. On this respect, cross-linguistic effects and some factors (e.g. language typology, L1 or L2 transfer) are also presented in this current study.

\subsection{Method}

In this research, observational case study method has been used and the data was collected in the classroom environment. As Mertler, (2009: 79) expressed, observational case studies can be the most common type of case study and the focus of them "might be a particular physical location in the organization" (Italian language course in this study) or "a specific group of people" (Italian language learners in this study). In other words, the researcher aimed to look at the nature 
Demiray Akbulut, F. (2020). The effect of first and second language on the third language: An observational study. International Journal of Social Sciences and Education Research, 6(3), 294-310.

of L3 acquisition process that took place in the language course environment for three months. To structure a natural setting environment and to prevent the negative influence of observer existence in the classroom, the researcher preferred to become an integral part of the study. Thus, to achieve the "trusted person" status (Glesne, 2006; Mertler, 2009) the researcher has continued to be seen as the participant and 'participant observation' has been structured in this current study. In this context, the observations have been made for a certain period of time and implications from narratives of participants and notes of the researcher have been analysed.

\subsection{Participants}

The participants of the study consisted of 7 individuals studying Italian for different purposes in a private language course in Rome, Italy. Although the mother tongue of the participants was different, individuals who had a second language of English or French and were learning Italian as a third language were preferred. The overall aim of the study was to examine the effect of the first or second language on the third language acquisition.

The first of the participants was a 70-year-old American individual and wanted to learn Italian for personal reasons. She stated that she did not know any Italian words yet when she came to Italy, but she had been attending the same course for 9 months and that reached a very good level of Italian knowledge in this period. The other participant was a dietician from England who decided to live and found an occupation in Italy. She stated that she had already taken Italian language courses and she was at B2 level and came to the course only to meet the practical and speaking deficiencies. Another participant aimed to learn Italian by coming from Germany in line with her own special wishes. Her second language was French because her husband was French, and her children were bilingual individuals in French-German. At that time, she aimed to learn Italian at a better level after French. Another participant was a Spanish individual, who came to Italy for business and education from Argentina. She spoke English as a second language at a good level and aimed to learn Italian. The other participant was a student who came to Rome from Libya for educational purposes. He attended this course in order to achieve B2 level success from CILS exam. He spoke English as a second language at a good level. Another participant was a Japanese individual and spoke English as a second language. Due to his being an architect and admiration to Rome, he tried to learn Italian at a good level and visited Rome almost every year as a tourist. The last participant was a Turkish individual who came to Rome for academic purposes and participated in this language course. She knew a good level of English and learned Italian in a language course in Rome 8 years ago.

Table 1. Description of participants

\begin{tabular}{llcccccc}
\hline & Age & Gender & L1 & L2 & AoA* & L3 & $\begin{array}{c}\text { L3 LET* } \\
\text { (month) }\end{array}$ \\
\hline St_1 & 70 & F & EN* & FR & 12 & IT* & $>12$ \\
St_2 & 27 & F & EN & FR & 18 & IT & $>10$ \\
St_3 & 55 & F & GER* & FR & 20 & IT & $>12$ \\
St_4 & 40 & F & SP* & FR & 11 & IT & $>12$ \\
St_5 & 24 & M & ARA* & EN & 14 & IT & $>18$ \\
St_6 & 60 & M & JAP* & EN & 12 & IT & $>10$ \\
St_7 & 34 & F & TR* & EN & 15 & IT & $>18$ \\
\hline
\end{tabular}

*EN: English, GER: German, SP: Spanish, ARA: Arabic, JAP: Japanese, TR: Turkish, FR: French, IT: Italian, AoA: Age of Acquisition, LET: Language Exposure Time

Copyright (C) by International Journal of Social Sciences and Education Research ISSN: 2149-5939 
Demiray Akbulut, F. (2020). The effect of first and second language on the third language: An observational study. International Journal of Social Sciences and Education Research, 6(3), 294-310.

\subsection{Data collection}

The researcher participated in the study as an observer at Italian language course. She was able to observe both teacher's attitudes and students' interactions with the others in a variety of social contexts. The researcher also observed students in the process of Italian language acquisition as L3 in the classroom. During the observation, the researcher carefully observed the student behaviour and took notes. She also participated in the context and shared some information with course teachers, took notes and constructed a diary format. She kept her accounts in an "event-based diary format" (Duff, 2008; Peçenek, 2011) by expressing the information given from participants in a time sequence day by day from Monday to Friday and noted down remarkable errors in spoken or written language. Within this frame, the researcher collected data from students' productions in L3 in the classroom environment in an unstructured way. In addition, the researcher observed the students in their natural setting. Thus, the data for this study consisted of researcher's observational notes from the point of teacher and students.

\subsection{Descriptive data and analysis}

The researcher puts together her own notes from observational points in the classroom and natural setting. The data collected from classroom were given both in detail and summary since the procedure belonged to 3-months period. The only language spoken in the class was completely Italian. The teacher did not prefer to speak English or French as a common language in the classroom.

\section{From researcher's narratives.}

From the first day of the language course, every participant has taken a placement test. According to the results of the study, the classes are divided into different categories. The class which was observed was in the degree of third level, so it was equal to B1. The students have taken their seats. Since it was the first day of the third level, the teacher wanted to introduce herself to others. Afterward, the students introduced themselves. Since the teacher did not know any other foreign language including English, the lessons were always in Italian. (9 September 2019)

As can be stated in this excerpt; the teacher motivated the students to use only Italian language by expressing them that she had no knowledge of any other language. In other words, she aimed to build a target language environment among participants.

\subsubsection{Data about vocabulary skills}

The first data about vocabulary acquisition have been presented from notes which were taken by the researcher during the course. When these notes were summarized, it was seen that students who knew English as a second language (L2_EN) had morphological difficulties when they were compared with students who knew French as a second language (L2_FR). According to researcher's notes and comments, they did not understand the meaning of some words; they were participating in activities by estimating from some basic vocabulary items and trying to translate some words into English.

In this example, L2_EN participants were too late to answer by saying the opposite of words than L2_FR students although they were good at understanding the meaning of new vocabulary items. 
Demiray Akbulut, F. (2020). The effect of first and second language on the third language: An observational study. International Journal of Social Sciences and Education Research, 6(3), 294-310.

Table 2. An example of a conversation between teacher and students

\begin{tabular}{|c|c|c|}
\hline \multicolumn{3}{|c|}{ T: Dimmi i contrari di queste parole. 'Tell me the antonyms of these words.' } \\
\hline T: Arrabiarsi & & 'get angry' \\
\hline L2_FR: Calmarsi & L2_EN: Calmare* & 'calm down' \\
\hline T: $\bar{C}$ Cucire & & 'sew' \\
\hline L2_FR: Scucire & & 'unstitch' \\
\hline T: $\overline{\text { Migliorare }}$ & & 'improve’ \\
\hline L2_FR: Peggiorare & & 'get worse' \\
\hline $\mathrm{T}: \bar{I}$ segnare & & 'teach' \\
\hline L2_FR \& EN: Imparare & & 'learn' \\
\hline $\mathrm{T}: \bar{A}$ vvicinarsi & & 'approach' \\
\hline L2 FR: Allontanarsi & & 'go away' \\
\hline
\end{tabular}

From the researcher's narratives.

The students have started to do vocabulary activities such as finding the synonyms or antonyms of some words given by the teacher. L2_EN students partially understood and answered basic words while L2_FR students could respond correctly almost all vocabulary items. (12 September 2019)

From the Japanese student's narratives.

I think being in a different language family is the biggest problem. When I speak in Italian, I constantly think of Japanese words. First, I translate the Japanese words in my mind into English, then I translate them into Italian. There is a constant translation mechanism in my mind, and I feel tired at the end of the lesson.

Table 3. An example of a conversation between teacher and L2_FR student

\begin{tabular}{ll}
\hline T: Che cosa hai fatto ieri? & 'What did you do yesterday?' \\
S: Ho fatto una passeggiata nella citta. & 'I had a walk in the city'. \\
T: Citta o centro? & 'city or centre?' \\
S: Ah, si, centro. & 'Ah, yes, centre'. \\
\hline
\end{tabular}

In this example, L2_FR student preferred the word citta instead of the 'centre', since the word citta is used to mean the 'city centre' in French. The biggest problem experienced by L2_FR students was seen in the usage of words. They had difficulties in choosing words and often made mistakes using the words imported from French.

From English student's narratives.

I feel as if my mother tongue (English) does not make any contribution to me. Because when I speak in Italian, I speak very slowly and my mind uses French which is the second language I know. In word selection, I use the same proportion of words in Italian as much as I speak French. I also can't remember the Italian equivalent of a word if I don't know the meaning of it in French.

\section{From German student's narratives.}

My mother tongue is German and I live in Germany. My husband is French and my children are naturally raised bilingual. They speak both French and German like their mother tongue. I didn't have a hard time while learning Italian. Because it is very similar to French. I feel very lucky to have learned French beforehand. At first, there were some points that I 
Demiray Akbulut, F. (2020). The effect of first and second language on the third language: An observational study. International Journal of Social Sciences and Education Research, 6(3), 294-310.

had difficulty with. Although I see myself quite well as syntactic or grammatical, my biggest problem was to translate French to Italian, morphologically. While this transfer worked most of the time, sometimes I made mistakes due to incorrect transfers.

From the teacher's narratives.

From beginner to advanced, student profiles vary widely. Students who speak French and Spanish are quite many. There are also students who speak English or Arabic. Students who have Turkish mother tongue and who know English very well are also coming to our course. If I make a comparison in terms of vocabulary knowledge, students who speak French and Spanish have more difficulties at the beginning level than other students. Because they always make code-mixing or code-switching, -especially Spanish students -; because they think that we understand them in all circumstances. However, students whose mother tongue or second language are typologically different from Italian are making faster progress at the beginner level. On the other hand, when they reach $3^{\text {rd }}$ or $4^{\text {th }}$ level (B1 or B2), students whose mother tongue or second language is French or Spanish progress much faster, while students whose mother tongue or second language is from a different language family stay at a certain level and slow down. It becomes very difficult for them to go to the next level.

As it was seen from the notes, L3 learning is more strongly affected by more typologically similar languages (Rothman, 2015; Chen, 2018). Also, as in the example of "city" and "centre", L3 words took the nearest translation equivalents in L2 words as long as L2 is at a high proficiency level.

\subsubsection{Data about syntactic skills}

From syntactic aspect, the biggest problem has been seen in the conversation of Turkish and Japanese students. Whatever their second languages are, they had similar problems.

Table 4. An example of a conversation between teacher and L2_ENG student

T: Si F., puoi raccontare un libro o un film che hai letto o visto?

'Can you narrate a book or a film that you have read or seen?'

$\mathrm{S}$ : Si, vorrei raccontare un drammatico film.

'Yes, I would like to narrate a dramatic film.'

T: Un film drammatico?

'a dramatic film'

S: Si, la storia di Black film raccconta di una sordocieca ragazza e si chiama Michelle.

'Yes, the story of the film Black narrates a deaf-blind girl and her name is Michelle.'

T: Di una ragazza sordocieca! Si chiamava Michelle!

'of a deaf-blind girl! Her name was Michelle'

In this example, the teacher asks the student to describe a book she has read or a movie she has watched. The student transfers from his second language, English, and uses adjective + noun (un drammatico film) structure. However, noun + adjective (un film drammatico) structure is more valid in Italian and therefore the teacher emphasizes and asks the student to correct the mistake.

From Turkish student's narratives.

My mother tongue is Turkish and I know English at an advanced level. On the lexical level, the more I am familiar with the English language, the more I can master the Italian 
Demiray Akbulut, F. (2020). The effect of first and second language on the third language: An observational study. International Journal of Social Sciences and Education Research, 6(3), 294-310.

language because there are so many similar words between English and Italian. However, from a syntactic point of view, there are some difficulties. I am still having difficulties in the SOV order, my mind is sometimes shifting to Turkish. In fact, at some point, I can say that I use also English rules in Italian. For example, in English, adjective is used before the noun (a beautiful girl), but in Italian, adjective usually comes after the noun (una ragazza bella).

Table 5. An example of conversation between teacher and L2_ENG, L1_JAP student

T: Tu che fai nella tua vita' quotidiana per salvare l'ambiente?

'What are you doing in your daily life to save the environment?'

S: Salvare l'ambiente e' molto importante. (S-V-O) Io, l'etichetta di vestiti, guardo. I mean [in English] Io guardo l'etichetta di vestiti.

'Saving the environment is very important. I, the label of clothes, look at. I mean, I look at the label of clothes.'

In this example, the teacher asked the student what he was doing to protect the environment. While the student responds, he uses the SOV structure instead of the SVO structure by transferring from his native Japanese.

\section{From Japanese student's narratives.}

What is interesting is that, in terms of sentence order, when I speak in Italian, my mind is shifting completely to Japanese, my mother tongue. As soon as I made a mistake, I notice it, but I am late to correct them immediately. As I said before, the reason why I am late to correct myself can be the translation effect in my mind; since I first translate them into English and then Italian.

From syntactic aspect, it was observed that Turkish and Japanese students have transferred their mother tongues to L3 production. Although they have a good level of English as an L2, they still used their L1s.

\subsubsection{Data about reading and speaking skills}

From the perspective of reading skills, Japanese and Arabian students stated that they experienced the most difficulty in reading activities since they spent a lot of time on reading. The common idea was that the different alphabets and some sounds they used in their mother tongue caused them to be slow in reading comprehension and make mistakes. Although both spoke English as a second language, they claimed that their mother tongue was more dominant than English (L2) in reading.

Table 6. An example of a conversation between teacher and L1_ARA student

\begin{tabular}{lc}
\hline T: Che cosa vuoi parlare? & 'What do you want to talk about?' \\
S: Voglio ballare sul terrorismo. & 'I want to dance (!) about terrorism.' \\
T: Vuoi parlare? & 'want to talk?!' \\
S: Si, si parlare & 'Yes, yes talk' \\
\hline
\end{tabular}

Similarly, while speaking, as the researcher indicated, the student whose mother tongue is Arabian made some transfer from Arabian to Italian language. It was seen that he used certain features of Arabian phonology in Italian. For instance, in Arabian, the consonant $<p>$ does not exist. Instead, the consonant $<\mathrm{b}>$ and different versions of $<\mathrm{b}>$ are used. On the other hand, in

Copyright (C) by International Journal of Social Sciences and Education Research

ISSN: 2149-5939 
Demiray Akbulut, F. (2020). The effect of first and second language on the third language: An observational study. International Journal of Social Sciences and Education Research, 6(3), 294-310.

Italian, the consonant $<\mathrm{p}>$ is mostly used and it is different from $<\mathrm{b}>$. Thus, this fact caused interference in student's spelling of the words including $<\mathrm{p}>$ such as buzzare instead of puzzare, bulire instead of pulire.

In this sample, in fact, he would like to say parlare, but he pronounced it as if it is the sound of " $b$ ". Although the teacher understood what he meant to say, she emphasized the correct spelling of the word to make him notice where he made the mistake.

From Arabian student's narratives.

There is nothing I can do. Yes, I know English, but I have lots of difficulties in reading Italian texts because my mother tongue is Arabic. I am quite inadequate in pronunciation because I read the words wrong. I am constantly trying to read the texts written in Latin alphabet from left to right, while speaking with a different alphabet from right to left in my daily life. Also, the lack of $\langle p>$ voice in Arabic is a big problem for me. Instead of this voice, I constantly speak with $<b>$ and I have a lot of problems in speaking and being understandable.

There is also another student who had a problem with Italian pronunciation. Since her mother tongue is Spanish she expressed that she did many mistakes using Spanish sounds at the beginning of the course.

\section{From Spanish student's narratives.}

My mother tongue is Spanish, I know English as a second language. While I was learning Italian, of course I used Spanish, not English. But initially, that was very tiring for me. From the first day of the course, I wanted to completely forget Spanish because I was speaking Spanish unconsciously in the classroom. When I reach level 3 and 4, I transmit less because I have learned Italian better.

From this perspective, as Typological Primacy Model (TPM) proposed the factor that determines the source language in the transition between languages in multilingual environments may be the typological affinity existing. In this case, it can be said that transferring the features can be explained with the existing or perceived typological proximity of the languages (Oztekin \& Haznedar, 2015; Rothman, 2015).

\subsubsection{Data about grammar and writing skills}

By examining the detailed notes of the researcher, some inferences have been made in the context of grammar and writing skills. First, when the participants' background information was taken, it was seen that they all first learned tempo presente (simple present or present continuous), then learned tempo passato prossimo (simple past tense) and tempo future semplice (future tense) in Italian. Afterwards, they learned tempo imperfetto (the past continuous tense) and they all used these tenses in oral production successfully. The observational notes by Petrilli (1997) on late learners showed that the students in the classroom used mostly present, past and past continuous tenses. In a similar way, in the language course, the participants mostly used simple present, present continuous and simple past tense but they rarely preferred to use future tense. Another important point in the notes is that, L2 EN students were always more successful and faster than FR students in terms of grammatical activities such as fill in the blanks (tenses), choose the correct option (conditional sentences) or rewrite (contracted forms). 
Demiray Akbulut, F. (2020). The effect of first and second language on the third language: An observational study. International Journal of Social Sciences and Education Research, 6(3), 294-310.

Table 7. An example of a rewrite activity between teacher and students

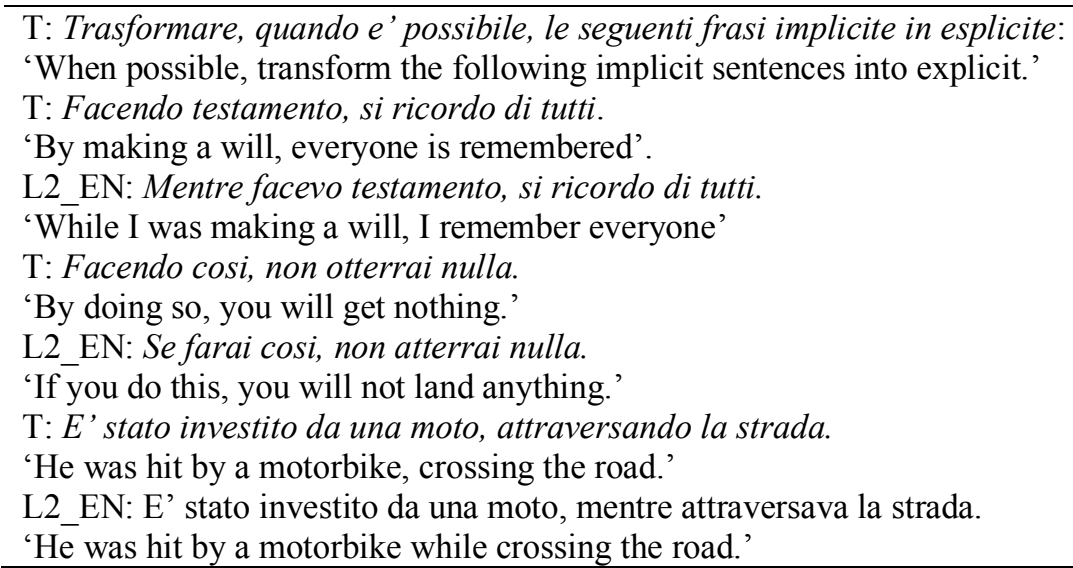

In the above activity, L2_EN students were faster than L2_FR students in answering to rewrite sentences. There may be two reasons for this: first, knowing and similar learning way of English as an L2 might help them to transform the sentences in the correct form. Second, L2_FR students were busy to think the gerund form of the vocabulary items since they are similar to French words, thus they might have been mixed and late to transform the sentences.

From the perspective of observed grammatical judgement of the students in writing, some samples from the students were analysed in detail (see Figure 1.).

Figure 1. Writing sample 1.

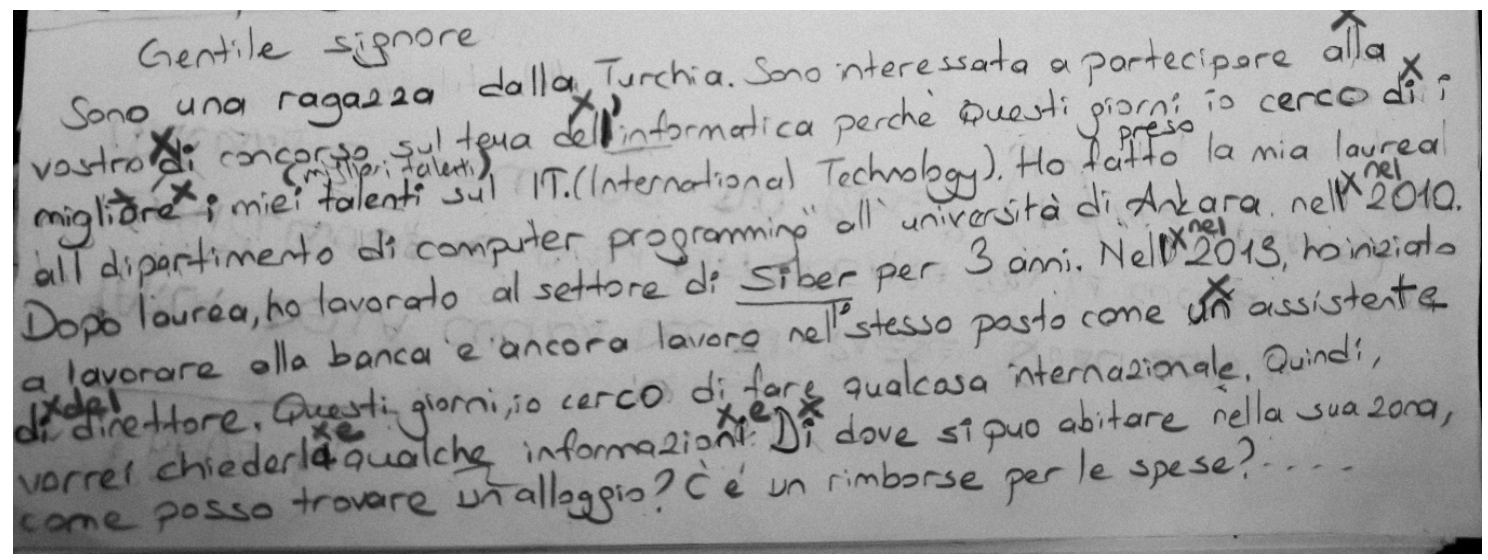

[Roma, 14 October 2019. Sei interessato a partecipare un bando di concorso che ti consentirebbe di frequentare un master prestigioso all' estero sul tema del informatica. Scrivi una mail alla segreteria dell master dove: spieghi perche' sei interessato al master, parli della tua esperienza formative e lavorativa in questo settore, chiedi informazioni sulle condizioni (alloggio, rimborsi speze...) (80-100 parole)]. ['You are interested in participating in a competition that would allow you to attend a prestigious master abroad on the subject of computer science. Write an email to the secretary of the master and explain why you are interested in the master, talk about your training and work experience in this sector, ask for information on the conditions (accommodation, special reimbursements ...) (80-100 words).']

This writing sample was taken from Turkish student and the errors were corrected by the teacher. It can be easily seen that student did not use prepositions correctly. In terms of articles, she misused or overused them. There can be observed the typological effect of L1 and L2 since

Copyright (C) by International Journal of Social Sciences and Education Research

ISSN: 2149-5939 
Demiray Akbulut, F. (2020). The effect of first and second language on the third language: An observational study. International Journal of Social Sciences and Education Research, 6(3), 294-310.

they differ from L3 Italian. It can be said that the cross-linguistic effect can explain this situation. In Italian, the gender position of nouns (masculine and feminine) and the singular or plural features of them differs from Turkish. The leading article (generally by the final vowel) is used to show the gender and number. However, in Turkish there are no noun classes or grammatical gender. Thus, the student misused the plural form of the nouns such as in 'infomazioni' instead of writing 'informazione'. It can be stated that she made an overgeneralization in the singular-plural form of the noun. In Turkish, there is no definite article stated in Turkish. Thus, the reason for this can be that there is not any existence category of article in Turkish and student misused them in Italian. Furthermore, the student confused the usage and had difficulty in applying the usage of prepositions such as "del or dell', nel or nell".

From Turkish student's narratives.

In Turkish or English there is no masculine or feminine aspect. While I am talking in Italian with my friends in the classroom or outside, I cannot talk fast and fluently. Because I have to think twice as much as my other Italian-speaking friends. First of all, I have to decide whether the word is male or female. Then I have to bring an article by gender and this article rule is not available in Turkish or English. After deciding on the article, I have to think about the sentence order. For example, first I have to bring noun and then adjective. This rule is different from English. The predicate always has to come after the subject. In short, my job is twice as much and harder as other Italian learners.

There is also another example on prepositions taken from researcher's notes. It shows that, the similar way of languages is another caveat to use a new language fluently. Since L1_English and L2_French participant thought that most grammar points were similar to each other, they overused some aspects or generalized some rules to Italian.

Table 8. An example of a preposition activity between teacher and L1_ENG, L2_FR student

T: I danni causati per* temporale sono importanti. (dal)

'The damage caused by storm is important.'

$\mathrm{T}$ : Fate attenzioni per* non perderlo (a).

'Be careful not to lose it'

T: Corri per* prendere il libro! (a).

'Run to get the book!'

In the activities of preposition, the participants had the most difficulty to find the correct preposition. L2_FR or EN students had the errors using the prepositions dal (from or by) or $a$ (to), instead they always preferred per (for). The prepositional aspect was seen for them challenging and it can be said that they avoided using prepositions like articles.

From English student's narratives.

My mother tongue is English and I learned French as a second language. Since I want to live and work in Italy, I am trying to learn Italian. Initially, it was very difficult for me to learn Italian words. But as time went on, thanks to French as a Latin language, I was able to learn Italian more quickly. However, prepositions and articles are among the most challenging issues for me. I think that translation should not be done while practicing prepositions. Because it is a very different subject from both French and English. 
Demiray Akbulut, F. (2020). The effect of first and second language on the third language: An observational study. International Journal of Social Sciences and Education Research, 6(3), 294-310.

From the same perspective, conditional sentences in writing is another challenging subject for students. As another writing sample, the usage of conditionals was analyzed as in the Figure 2.

Figure 2. Writing sample 2

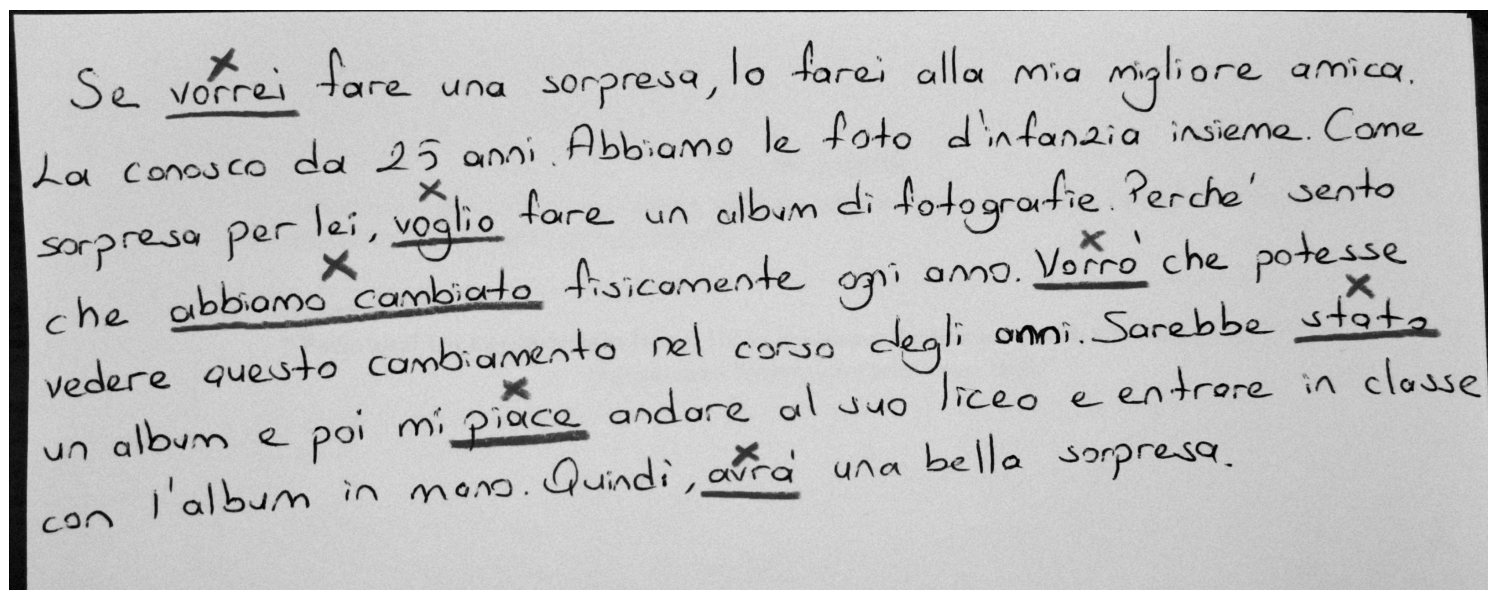

[(Roma, 25 October 2019. Se dovessi organizzare una sorpresa per un amico/a, che cosa farei. 7080 parole).] ['If you had to organize a surprise for a friend, what would you do (70-80 words).']

Se vorrei (volessi) fare una sorpresa, lo farei alla mia migliore amica. La conosco da 25 anni. Abbiamo le foto d'infanzia insieme. Come sorpresa per lei, voglio (vorrei) fare un album di fotografie. Perche' sento che abbiamo cambiato (siamo cambiate) fisicamente ogni anno. Vorro' (vorrei) che potesse vedere questo cambiamento nel corso degli anni. Sarebbe stato (sarebbe) un album e poi mi piace (piacerebbe) andare al suo liceo e entrare in classe con l'album in mano. Quindi, avra' (avrebbe) una bella sorpresa.

'If I wanted to do a surprise, I would do it to my best friend. I've known her for 25 years. We have childhood photos together. As a surprise to her, I would like to prepare a photo album. Because I feel that we have changed physically every year. I wish she could see this change over the years. It would be an album and then I would like to go to her high school and go to class with the album in hand. So, she would have a nice surprise.'

In this example, it can be observed that the student made conditional-subjunctive agreement error in terms of conditionals. She avoided the conditional form; however, as seen in the writing sample, she preferred to use presente indicativo, 'simple present tense' or tempo futuro 'the future tense'. As Peçenek (2011) indicated,

"Italian has a conditional verb inflection called the condizionale. The conditional mood is potential; expressing what should or would happen under certain circumstances. In addition, it is used in the conclusion of a conditional sentence. When the possibility of an action being fulfilled is subject to a condition referring to the future, it can be expressed either by the simple future in both clauses or by the imperfect subjunctive in the conditional clause and the conditional in the concluding clause (p.279)."

For instance: Se supererai l'esame, potrai avere una borsa di studio 'If you pass the exam, you can have a scholarship'. Se avessi dei soldi, comprerei una bella casa al mare. 'If I had some money, I would buy a nice beach house'. Thus, it can be easily said that, the students have made these errors because the acquisition process of Italian is different from English or French. In addition, the student made grammatical errors in using the verb 'essere' and 'avere'. In Italian, 
Demiray Akbulut, F. (2020). The effect of first and second language on the third language: An observational study. International Journal of Social Sciences and Education Research, 6(3), 294-310.

essere is used with intransitive verbs, while avere is used with transitive ones. The verb 'change' is an intransitive verb in Italian, and it should be used with 'essere' (e.g. siamo cambiate). Also, there should be plural agreement (-e) at the end of the verb. However, she used cambiato instead of cambiate. In Italian, when two or more feminine nouns are used as subjects and the verb is intransitive (e.g. essere is used), the verb itself is also conjugated by the noun and its plural form is done by the suffix -e not -o. This rule is completely different from Turkish or English, so she omitted it from her writing.

\section{Conclusion and discussion}

The first point of cross-linguistic effect to be emphasized is vocabulary skills. In the third language acquisition, it is quite possible to see the effects of the first or second language vocabulary knowledge. When the morphological effects of the first language on the acquisition of the third language are examined, it is seen that the participants whose native language is English, German and Spanish provide easier word acquisition and can use the language more fluently than Arabic and Turkish native speakers. Italian words are structurally similar to English, German or Spanish, and thus that makes word acquisition easier. However, the biggest problem of these participants is at the point of code-switching and code-mixing. These participants face more transfer effects than others. Participants whose native language is Japanese, Arabic and Turkish refer to English, which is their second language in word selection. However, it is observed that they are not as fast and successful as the participants who transfer the words from their mother tongue. The common opinion they have stated in the notes is that if they do not know the meaning of new Italian word in their second language, it is very difficult for them to put it into long-term memory. That is, in order for a word to be permanent, they must know its equivalent in the second language. Otherwise, they can quickly forget that word or cannot use it in context correctly. From these results, it can be seen a close relationship to the findings of Chen (2018) in which it is suggested that if learners cannot find the similar forms in the already-learned languages while learning L3, they will choose the closest translation equivalents in L2. At this point, language instruction has an important effect in selection, and it will provide the nearest translation equivalents of L3 words. Similarly, from another perspective, As Wei (2006:88) indicates;

"the multilingual mental lexicon contains not only lexemes but also language-specific lemmas; language-specific lemmas may activate language-specific morphosyntactic procedures in speech production, and third language learners' activation of lemmas for target language items may be influenced by the lemmas already stored in their mental lexicon through their previous language acquisition, especially second language acquisition. (p.88)"

Concerning syntactic skills, the biggest problem is seen in the participants whose native language is Turkish and Japanese, while the other participants do not have much difficulty in terms of syntax. The fact that Turkish and Japanese are structurally similar to each other and different from Italian as a Latin language clearly explains this result. While the Italian syntax is S-V-O, the syntax takes place differently in Turkish and Japanese. Therefore, during the sentence building, these two participants can change the location of the subject and verb or perform the syntax within the sentence similar to their mother tongue. Although both speak English as a second language, they state that they are transferring from their mother tongue not from second language. From a syntactic point of view, it is seen that the effect of the first language is more than the second language in the acquisition of the third language. As it was mentioned before, LPM claims that

Copyright (C) by International Journal of Social Sciences and Education Research

ISSN: 2149-5939 
Demiray Akbulut, F. (2020). The effect of first and second language on the third language: An observational study. International Journal of Social Sciences and Education Research, 6(3), 294-310.

all languages acquired beforehand stay active through the learning of L3 (Westergaard et al.,2017). Thus, the findings of this study show a different result from Bardel and Falk (2007:459) who express, "syntactic structures are more easily transferred from L2 than from L1 in the initial state of L3 acquisition (p.459)".

In terms of analysing reading and speaking skills, the biggest difficulty belongs to the participants whose native language is Japanese or Arabic. These are the participants who experienced the most difficulty in reading activities performed by the teacher in the classroom. The common idea that arises in the interview with them is that the different alphabets and some sounds they use in their mother tongue cause them to make mistakes. Although both speak English as a second language, they claim that their mother tongue is dominant in their reading activities or while speaking. However, it is an undeniable fact that their English also has a facilitating effect. Participants whose native language is English, German, Spanish or Turkish state that they did not experience any difficulties while reading or speaking. Thus, although the second language has a significant effect, the native language has a greater effect.

The last but not the least important point to highlight is the grammar and writing skills. Grammatical results appear to be the most meaningful results. When the grammar activities performed in the classroom are examined, it can be observed that the effect of the mother tongue is very low and the effect of the second language is more dominant. Participants whose second language is English make less errors than those whose second language is French. At this point, it can be thought that the knowledge and experience gained by the participants while learning the second language facilitate their third language acquisition process. Therefore, it can be concluded that English as a second language may be acquired differently from French. At some points, participants who have acquired French as a second language are more successful than other participants such as in using articles, prepositions. Nevertheless, it can be said that L2_EN participants can understand new subjects more easily (tenses, conditionals and so on) and be faster in many activities (fill in the blanks, rewrite, cloze tests and so on). Thus, it seems possible to say that the effect of the second language is more dominant than the first language in the acquisition of a new grammar.

As a result, there is not only one appearance in transfer between languages and cross linguistic effects. In other words, learners resort to different languages for different linguistic categories in L3 production (Efeoğlu, Yüksel \& Baran, 2019). It can be said that TPM, the language processor in learners' mind firstly identifies the most similar language and then use its grammar or other structures in acquiring L3. However, learners may also make a negative transfer from the other language which is not typologically close to L3 as seen in reading and speaking activities. Thus, it can be said that the proficiency level or L2 language instruction may affect this transfer procedure and they can select a non-facilitative source of transfer. From educational pedagogy, it can be concluded that, in L3 teaching and learning process, all factors should be considered (including L1 transfer, L2 proficiency level and so on) and individual-based teaching process should be applied.

\section{References}

Anderson, R. (1983). Transfer to somewhere. In S. Gass \& L. Selinker (Eds.), Language transfer in language learning (pp. 177-201). Rowley, MA: Newbury House.

Copyright (C) by International Journal of Social Sciences and Education Research ISSN: 2149-5939 
Demiray Akbulut, F. (2020). The effect of first and second language on the third language: An observational study. International Journal of Social Sciences and Education Research, 6(3), 294-310.

Bardel, C., \& Falk, Y. (2012). Behind the L2 status factor: A neurolinguistic framework for L3 research. In J. C. Cabrelli Amaro, S. Flynn, \& J. Rothman (Eds.), Third language acquisition in adulthood (pp. 61-78). Amsterdam, The Netherlands: John Benjamins Publishing.

Bardel, C. \& Falk, Y. (2007). The role of the second language in third language acquisition: The case of Germanic syntax. Second Language Research 23(4): 459-484.

Cenoz, J. (2001). The effect of linguistic distance, L2 status and age on cross-linguistic influence in third language acquisition. Cross-linguistic influence in third language acquisition: Psycholinguistic perspectives, 111(45), 8-20.

Chen, J. (2018). How do L3 words find conceptual parasitic hosts in typologically distant L1 or L2? Evidence from a cross-linguistic priming effect. International Journal of Bilingual Education and Bilingualism, 1-16.

Cook, V. (1995). Multi-competence and the learning of many languages. In M. Bensoussan, I. Kreindler, \& E. Aogáin (Eds.), Multilingualism and language learning: 8/2. Language, Culture and Curriculum (pp. 93-98). Clevedon, UK: Multilingual Matters.

De Angelis, G., \& Selinker, L. (2001). Interlanguage transfer and competing linguistic systems in the multilingual mind. In J. Cenoz, B. Hufeisen, \& U. Jessner (Eds.), Cross-linguistic influence in third language acquisition: Psycholinguistic perspectives (pp. 42-58). Clevedon, UK: Multilingual Matters.

Dewaele, J. (2001). Activation or inhibition? The interaction of L1, L2 and L3 on the language mode continuum. In J. Cenoz, B. Hufeisen, \& U. Jessner (Eds.), Cross-linguistic influence in third language acquisition: Psycholinguistic perspectives (pp. 69-89). Clevedon, UK: Multilingual Matters.

Duff, A. P. (2008). Case study research in applied linguistics. New York: Lawrence Erlbaum.

Efeoglu, G., Yüksel, H. G., \& Baran, S. (2019). Lexical cross-linguistic influence: a study of three multilingual learners of L3 English. International Journal of Multilingualism, 1-17.

Flynn, S., Foley, C., \& Vinnitskaya, I. (2004). The cumulative-enhancement model for language acquisition: Comparing adults' and children's patterns of development in first, second and third language acquisition of relative clauses. The International Journal of Multilingualism, 1(3).

Fuller, J. (1999). Between three languages: Composite structure in interlanguage. Applied Linguistics, 20 (4), 534-561.

Glesne, C. (2006). Becoming qualitative researchers: An introduction (ed.). PearsonEducation. Inc.: Boston, $M A$.

Grosjean, F. (2001). The bilingual's language modes. In J. Nicol (Ed.), One mind, two languages: Bilingual language processing (pp. 1-22). Oxford, UK: Blackwell.

Hammarberg, B. (2001). Roles of L1 and L2 in L3 production and acquisition. In J. Cenoz, B. Hufeisen, \& U. Jessner (Eds.), Cross-linguistic influence in third language acquisition: Psycholinguistic perspectives (pp. 21-41). Clevedon, UK: Multilingual Matters.

Hofer, B., \& Jessner, U. (2019). Multilingualism at the primary level in South Tyrol: how does multilingual education affect young learners' metalinguistic awareness and proficiency in L1, L2 and L3?. The Language Learning Journal, 47(1), 76-87.

Hopp, H. (2019). Cross-linguistic influence in the child third language acquisition of grammar: Sentence comprehension and production among Turkish-German and German learners of English. International Journal of Bilingualism, 23(2), 567-583.

Jarvis, S. (2000). Methodological rigor in the study of transfer: Identifying L1 influence on the interlanguage lexicon. Language Learning, 50, 245-309.

Kellerman, E. (1983). Now you see it, now you don't. In Gass, S. and Selinker, L., (Eds.), Language transfer in language learning. Rowley, MA: Newbury House, 112-134. 
Demiray Akbulut, F. (2020). The effect of first and second language on the third language: An observational study. International Journal of Social Sciences and Education Research, 6(3), 294-310.

Kellerman, E. (1995). Crosslinguistic influence: Transfer to nowhere? Annual Review of Applied Linguistics, $15,125-150$.

Mertler, C. A. (2009). Action research: Teachers as researchers in the classroom. Sage.

Murphy, S. (2003). Second language transfer during third language acquisition. Studies in Applied Linguistics and TESOL, 3(2).

Odlin, T. (1989). Language transfer. Cambridge, UK: Cambridge University Press.

Öztekin, E., \& Haznedar, B. (2015). Dillerarası etkileşim: Çokdilli ortamlarda sözdizimsel gelişim ve nesne düşürme. Boğaziçi Üniversitesi Eğitim Dergisi, 32(2), 37-47.

Peçenek, D. (2011). A longitudinal study of two boys' experiences of acquiring Italian as a second language: the influence of age. International Journal of Bilingualism, 15(3), 268-290.

Petrilli, R. (1997). L'Educaziıne linguistica nella scuola d'infanzia. Firenze: Guunti.

Poulisse, N., \& Bongaerts, T. (1994). First language use in second language production. Applied Linguistics, 15 (1), 36-57.

Ringbom, H. (1986). Crosslinguistic influence and the foreign language learning process. In M. Sharwood Smith \& E. Kellerman (Eds.), Crosslinguistic influence in second language acquisition (pp. 150-162). Oxford, UK: Pergamon Press.

Ringbom, H. (2001). Lexical transfer in L3 production. In J. Cenoz, B. Hufeisen, \& U. Jessner (Eds.), Cross-linguistic influence in third language acquisition: Psycholinguistic perspectives (pp. 59-68). Clevedon, UK: Multilingual Matters.

Rothman, J. (2015). Linguistic and cognitive motivations for the Typological Primacy Model (TPM) of third language (L3) transfer: Timing of acquisition and proficiency considered. Bilingualism: language and cognition, 18(2), 179-190.

Selinker, L., \& Baumgartner-Cohen, B. (1995). Multiple language acquisition: 'Damn it, why can't I keep these two languages apart?'. In M. Bensoussan, I. Kreindler, \& E. Aogáin (Eds.), Multilingualism and language learning: 8/2. Language, culture and curriculum (pp. 115-123). Clevedon, UK: Multilingual Matters.

Selinker, L., \& Lakshmanan, U. (1993). Language transfer and fossilization: The "Multiple Effects Principle.” In S. Gass \& L. Selinker (Eds.), Language transfer in language learning (Rev. ed., pp. 197-216). Philadelphia, PA: John Benjamins.

Shanon, B. (1991). Faulty language selection in polyglots. Language and Cognitive Processes, 6 (4), 339350 .

Slabakova, R. (2017). The scalpel model of third language acquisition. International Journal of Bilingualism, 21(6), 651-665.

Ullman, M. T. (2005). A cognitive neuroscience perspective on second language acquisition: The declarative/procedural model. Mind and context in adult second language acquisition, 141-78.

Wei, L. (2006). The multilingual mental lexicon and lemma transfer in third language learning. International Journal of Multilingualism, 3(2), 88-104.

Westergaard, M., Mitrofanova, N., Mykhaylyk, R., \& Rodina, Y. (2017). Crosslinguistic influence in the acquisition of a third language: The Linguistic Proximity Model. International Journal of Bilingualism, 21(6), 666-682.

Williams, S., \& Hammarberg, B. (1998). Language switches in L3 production: Implications for a polyglot speaking model. Applied Linguistics, 19 (3), 295-333. 